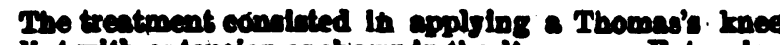
aplint with extendion as chiown in the dingrams. Intendow plagters are applled to the lep below. the fractene, and the Ifmb is paseed through the rlog, which encleclen the thigh at the groln, and which is paided over with felt, leather, and Impervious ollatin. The thigh is palled, and the extension if malntained by the plasters whlch are afficed

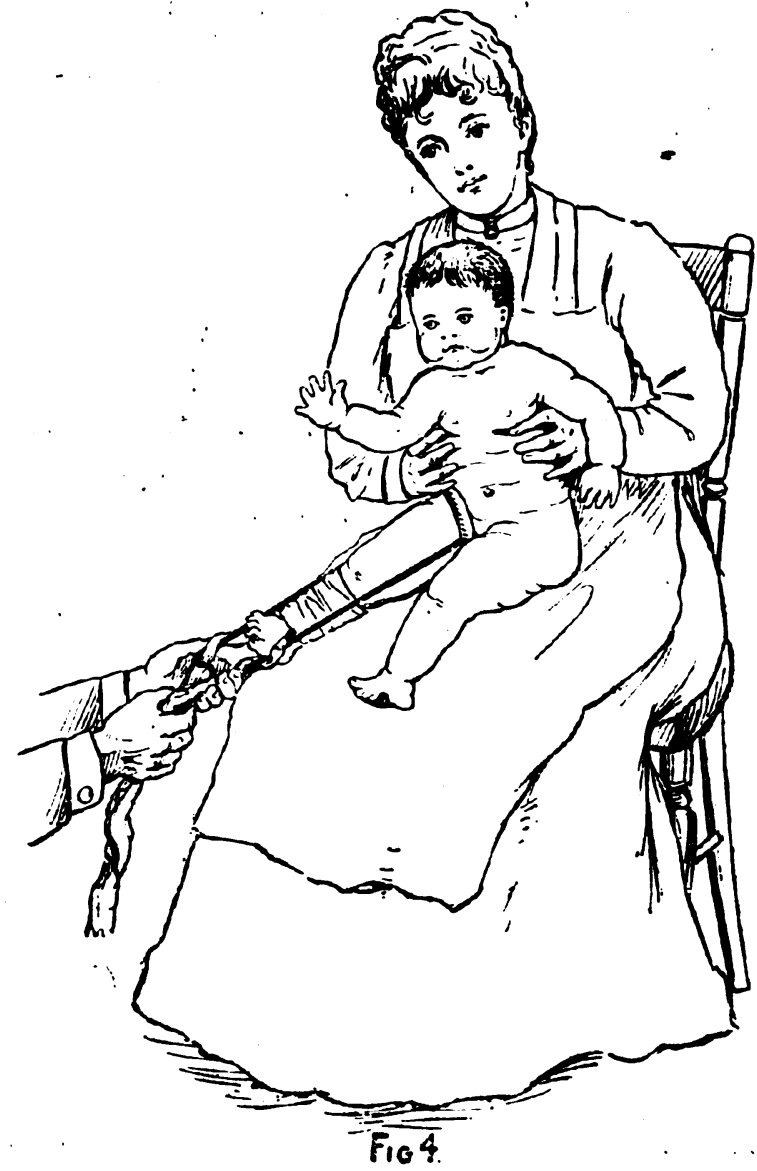

to the lower end of the aplint (Figs, 3, 4). A bandage is placed round the limb, and no further treatment is needed than now and agaln to extend the limb by pulling at the plasters. The little patient can be carried, nursed, left to play on the floor, and no displacement of fragments is possible. It can be applled easily in five minutes, whether the child struggles or not, and an ansesthetic is never needed. (Fige. 1, 2, 3, 4.)

REFERExce.
1 Fracture in Forcible Delivery, with the Prepentation of a Splint. Surgery, Gymaccology, and Obstetric8, Tebruary, 1908.

\section{PLASTIC RESECTION OF THE BREAST AND} ITS BEARING ON THE PRELIMINARY INCISION OF BREAST TUMOURS.*

By C. HAMILTON WHITEFORD, M.R.C.S., L.R.O.P.

Twenty-five years ago Thomas removed adenomata of the breast by enucleatiog the tumours through the deep anflace of the mammary gland, which was exposed by turning ap the breast by a curved incielon along the line of junction of the lower edge of the breast and the chest wall. He made no attempt to suture the cavity left by the enncleation of the tumour, and in the case of a carity In the upper part of the breast the distance Irom the ekin Inclaion would render suturing most difficult. Neither is it an eagy matter to obllterate a more or less apherical cavity whose walls are composed of breast tissue. Consequently. alter the removal of an adenoms of any olze, Thomas's operation reanlted in a considerable talling in of the okln over the site of the tumour.

Collins Warren has made a happs Improvement on

- Resd before the South-Western Branch of the British Medica Assoceation on 2 pr:1 15th, 1908.
Thomaplo opernttion ${ }^{2}$. He tound that an.inolnton made alous the outer edpe of the breant, and where necenary prolonged alowg the undernurface of the anterior axlllary fold, ante very complete a xees to the deep surfice of the mont remote reglons of the breast and resulted in.an Incomplonons ecar. He does not enucleste the tnmour, bat erolses the recrment of bresst in which the tumour lies and reconstruotes the breast by auturing together the edges of the wedge-shaped gap.

At a recent meeting of the Plymouth Medical Soclets I demonotrated a patient in whom I had removed, in November, 1907, for pernistent mastitla, from the upper and Inner ausdrant of the breast-the reglon which is least accessible, and which for the wearing of evening dress is most important-a wedge of breast tisene by Warren's method. The reanlt, in splte of the formation of a retro-mammary haomatoms which became infected, was really very fair. Four months after operation the breast was in Its natural position, the ekln over the resected aret was normal, showed no depression and only allght ousplalon of flattening.

This method exposes all the deep surface of the breast and ensbles the surgeon to inclse, on Its deep surface, tumour situated in any reglon of the mammary gland. If the tamour proves to be mallgnant, the cut surface of the tumour and adjacent breast tissue is cauterized, in order to minimlze the risk of dissemination of cancer cells. $\Delta$ pad of ganze is packed between the breast and the greater pectoral muscle, and the breast, tarned down into its natural position, is sutured to the greater pectoral muscle. $\Delta$ fresh get of gloves and instruments is taken, and the radical operation for canuer is performed in the usaal manner. If the tumour prove to be innocent the procedure is as follows: The segment of breast tlesue containlng the tumour is excised. The wedge-shrped plece removed Consists of the whole thickness of the breast, care being taken not to remove any of the subcutaneous lat. After ligature of every bleeding polnt, the contour of the breast is reconstructed by two las ers of interrupted catgut sutures. The first laser, Including the subcutaneous fat, bat not the aldn, approximates the superficial portions of the divided breast tissue. This lajer produces wrinkling of the ekln, which disappears when the sutnres have been absorbed. 'I'he second layer approximates the sides of the deep portion of the wedge-shaped gap. The breast is then turned down into Its natural position, and is attashed by 8 third laser of sutures to the edge of the greater pectoral muscle. A fourth layer of sutures closes the connective tlsone immediately beneath the skin incision, which is closed by sutures of either silk, linen thresd, or sllkworm gut. The breast is compressed by firm bendaging over the dressings.

Warren only employs dralnsge, which is mide through the lowest part of the skin incision, in cases known to be infected, as in absce6s. In the case referred to above Warren's advice as to omitting drainage was followed, and in spite of elaborate haemostasis by ligature $\mathrm{B}$, fllowed by firm bandaglng, a baematoma resulted.

In view of the extensive area Involved in the diescction It is probably eafer in every case to drain the retromammary tissues for twenty- Iour hours by a tube passed from the lowest part of the ekin incisicn to the deep surface of the sutured ares of the breast.

The skin over the lower portion of the breast In the case mentloned, its nerve supply belng cut off, was rendered at first almost completely ansesthetlc. Fonr months aiter operation this anserthesls had almost disappeared.

\section{Conorusrons.}

1. Every breast tumonr should be Incised prior to Its removal. The surgeon who, in performing a radical opera. tion f $J$ supposed mallguant disease of the breast, neglects the elementary precantion of Incising the tumour as 8 means of either confirming or disprovlng the diagnosis, runs the rlst of finding himzelf in the unenviable position of having performed Halsted's or some equally extensive operation for a simple tumour such as an adenoms or abscess.

2. The exploratory Inclsion should not be made through the skin whlch overlies the tumour. An incieion made into the tumour through the overlylog skln, In the event of the tumour proving non mallgasnt and needing only local removal, results to a certaiuty in a scar and prubably in a dep:easion. Th!s ecar, or ecar plus deprerslod, if 
ofturted in the epper half of the breat, Interferes atth the venring of 8 low-peated drem.

3. For explartion of, and if innocent for removel of, tumoure altuated in the apper hemlophere of the breats the indrian and method of Colling Warren choold be emplosed, becanse, in the event of the tumour proving Inmosent and needing simply locil removel, this mothod prevents a diofigurement whloh, to a censlitive pattont, is distreasing and, surglcally, is unnecessary.

RErzRencs.

1 Annals of Surgery, June, 1907.

\section{MEMORANDA : \\ MEDICAL, SURGICAL, OBSTETRICAL.}

ON $\triangle T R O P H Y$ OF THE PROSTATE AND ON MEASURING THE LENGTH OF THE URETHRA.

I sAT two cases recently of disseminated splnal cclecosis, accompanled by prostatic atrophy, and would much like to know if neurologists have noticed this. Both patients were middle-aged men. No trace of prostate conld be felt In elther ; in both Impotency and partial urinary retention existed, and in both also a catheter drew off the urine when passed 7 in. exactly. I say "exactly" because I wish to polnt out the inexact means usually adopted for measuring the urethra. This passage may vary in length fully an inch in the same person according to the degree the anterlor part is stretched over the instrument used, and this is important since knowledge of length accurately determined is a valusble aid in the diagnosis of prostatic alterations, and in the retention of catheters. Personally I always measure not only the anterlor urethra, but the degree the penis is stretched; this entalls no trouble. The length of the former deducted from the length of the catheter required to " tap " the urine shows, of conrse, the length of the deep urethra-the only measurement worth knowing. Finally, the proper way to drain the bladder by the nrethrs is not only to pass the catheter just the proper distance, but to pass it with Its eye lacing the trigone. Other things belng equal there will be no leakage and little irritstion.

JAMES MACMUNR.

LARGE THYMUS: SUDDEN DEATH.

ON the last vojage from New York to the Mediterranean with about two thoueand passengers on bosrd, I had a case whieh might be of interest to readers of the BRrTish Medicar Jouras. One morning at 5 o'clock I was called to attend a child in the steerage that was sald to be dying. $\Delta$ few minutes later I found a stewardess holding the child in her arms, and the parents and others standing around weeplng. The chlld was dead, and as nothing had been said to me the prevlous das regarding it, I naturally suspected that the mother had overlain It. I made ingulries and gathered the lollowing particnlars: Parents Austrian, above the average peasant intelligence, and apparently healthy. One other chlld died about a year prevlously, aged 6 months, cauge unknown, but also very sudden. This second child was a male, 3 months old, born in America, and with no hlstory of illnesses. On the previous evening it was quite well, and took ito milk as usual at 8 p.m., when it was put to sleep in its baby carriage, in the same room as the parents. When the latter retired at 10 p.m. It was sleepIng quietly, and was all right at 1 a.m., when the mother woke up. Abont 5 \& m. the father rose ap and looked into the ioby carriage, when he noticed the child's eyes turnIng up, and before I could be called there was a spasm, and immediately afterwards it lay still, desth having apparently taken place at that moment. I made a post. mortern examlnation and lound the bedy to be well developed, well nourlshed, and quite normal in appearance. On opening the thorax I found a very large thymus gland, extending nearly the whole length of the sternum and adberent to the pericardinm and to the pleurs on both sides. It extended backwards to the vertebrae and seemed to occupy a large part of the thorax. The heart and lungs were healthy, but displaced by the enlarged thrmus. The liver was much enlarged and the spletn enlarged. The stomach and Intestlnes were normal. The left kldney was somewhat enlarged, and both suprarenals were enlarged. The thyrold gland was glightly larger then norional tho brain we mother colt, with nome effuion on the cotter. The pineal gland was enlanged. Death was probably due to preesure on the varen by the enlared thrmon.

\section{DAVD D. F. MnomrYR, K.B., Oh.B.Glasg, Surgeon, Cunard R.Y. 8. Carpathia.}

ACUTE FARCAL IMPACTION IN TER RECTUM. Wirh reference to the case reported by Dr. W. M. Robson

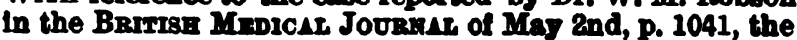
followlng casees mas be of interest:

Case I.-A little ahrivelled old woman was admitted to the Rojal Infirmary, Liverpool, a few jears ago, when I wes honse-physician to Dr. Richard Caton. Apart from great emaciation and apathy amounting almost to dementia, she appeared to have no special disease. Inspection of the abdomen showed visible peristalsis, and this was taken to polnt to chronic Intestinal obstruction. The patlent took verg little nourishment. Eramination of the rectum revealed a large rounded faecal mass, block. ing the anus like a ball valve, but allowing the pagsage of liquidd faeces to a certain extent. I removed the mase plecemeal with my fingers.

Cave II, of which I have no notes, was that of an Infant In ordinary health, and from 12 to 18 months old. The procedure was aimillar to that in the preceding case.

Case IIr, a well-bullt man about 24, wlth a mitral systollc brult, had a slight haemoptysis, and was, therefore, kept in bed, very still, and fed upon mill. One night I was sent for because he was in pain and conld not delaecate, in spite of aperient mediclne and a desire to do 80 . I lonnd the rectum filled with a ball of faeces like stlff clay, which the bowel was quite unsble to manage or the anus to pass. I removed thls as in the other cases, the operation causing considerable pain. The lump 78 almost as big as a fetal head, and the expulsion of the mass with assistance much resembled the act of parturition. The patient had been taking calcinm chlorlde, and this drug was probebly one of the chlef causes of the condition, by forming a dry calcareous motion. In none of the cases was there excessive loss of fluld, elther by diarrhoes or haemorrhage ; nor was there rectal feeding, as in Dr. Robson's cases, b it no doubt there was insuficient attention to the intefe of water, a point to be remembered in the prevention of the condition.

Liscard.

$$
\text { Bxymodr W. Davirs, M.B., Ch.B Tict. }
$$

BYDROGEN PEROXIDE IN PUERPERAL VEPSIS. Is view of Dr. Kngvett Gordon's paper on the treatment of pnerperal fever, and Dr. Hovenden's note on the use of hydrogen peroxdde in septic conditions, the following case may be of interest: I was called on the fourteenth day to see a puerperal woman who had been attended by 8 mldwife. The pulse 728 140, the temperature $104^{\circ}$; there was great pelvic pain and tenderness, and pus was seen oozing coplously through the os uterl. I curetted at once, then swabbed the uterine cavity thoronghly with pure lssol, and inserted a large double wick of sal alembroth ganze sosked in 1 per cent. lysol (removed next day). In few hours there was considersble Improvement. The rulse fell to 38 , the temperature to $103^{\circ}$, and pain and tenderness almost disappeared. In two days, however, she became as bad as when first seen-or Indeed worse. I again swabbed out the uterus, this time asing hydrogen peroxide solution (10 vols.) and draining with sterile lodoform ganze scaked in the solution. The effect was most striking. In three hours the temperature fell from $104.2^{\circ}$ to $100^{\circ}$, the pain vanlshed, and ghe looked llke a different woman. When the gauze had been In the uterus lor twenty. four hours she had a sudden rise of tempersture to $104^{\circ}$, and pulse to 120 ; but this was apparently due to the gauze ceasing to act as a drain and becoming a plug, for on its removal the temperature fell to $98^{\circ}$ and the pulse to 80 , and recovery proceeded amoothly. It should perhaps be mentloned that belore each uterine manipulation an attempt was made to dieconrage the vaginal germs by means of mercurial douches given with sterlle apparatus. Fowler's position was employed throughout. The point that seemed noteworthy in thls cage was the marked superiority of the hydrogen peroxdde over the pure lybol, both being used under practically identical conditions in the rame patipnt.

Nerrcastle-upon-Trnc.
V. T. Carruthers, Lieut., R.AMC. 